\title{
Fodbold som sprog: En kulturanalyse af udvalgte VM-nationer
}

Niels N. Rossing \& Lotte S. Skrubbeltrang

Aalborg Universitet

\section{Resumé}

Denne artikel har til formål at beskrive, hvordan handlinger på fodboldbanen er relateret til de forskellige landsholds og landes kulturelle forståelse af fodbold, og hvordan disse handlinger bliver til talte dialekter indenfor fodboldsproget. Med afsæt i Edgar Scheins teoretiske ramme for kultur, blev de brasilianske og italienske fodboldlandsholds kulturer undersøgt. Udgangspunktet for analysen var både dokument- og videoanalyse. Dokumenterne var for det meste videnskabelige undersøgelser og populære bøger omhandlende de nationale fodboldkulturer, mens videoanalysen inkluderede alle kampe med I talien og Brasilien fra verdensmesterskaberne i 2010 og 2014. Den kulturelle analyse viste en vis sammenhæng mellem de nationale fodboldkulturer og landsholdene, hvilket indikerede en national dialekt i spillets sprog. Hver national dialekt syntes at være baseret på forskellige grundlæggende antagelser og til en vis grad specifikke symbolske handlinger på banen. Handlingerne viste sig at være relativt dynamiske, hvilket sætter spørgsmålstegn ved den kulturelle stabilitet på landsholdene. Endvidere afslørede analysen også inkohærens mellem landsholdene og den brasilianske og italienske fodboldkultur generelt. Resultaterne sætter spørgsmålstegn ved ideen om landshold som et symbol på en særlig national fodboldkultur.

Selvom fodbold er blevet kaldt et stort kulturelt fænomen, synes der at være flere perspektiver på, hvilket fænomen fodbold egentlig er (Tomlinson, Markovits, \& Young, 2003). Historikeren Richard Holt argumenterer for, at fodbold er et spejl for dens tilhængere (Holt, 1989), mens Janet Lever argumenterer for, at fodbold fremmer social integration gennem ritualisering af konflikt (Lever, 1995). Antropologen Eduardo Archetti anser fodbold som et "rigt, komplekst, åbent scenarie, som skal tages alvorligt" (Archetti, 1992, s. 232). Inspireret af systemteori kan sport også opfattes som et samfunds funktionelle kommunikationssystem, fordi det nutidige samfund har behov for et system, som er i stand til at repræsentere distinktioner (Wagner \& Storm, 2013). Wagner og Storm argumenterer for, at kroppen er et fundamentalt kommunikationsmedium i sport (Wagner \& Storm, 2013). Tangen sammenkobler disse karakteristiske forskelle til sportens kodificering, som afslører spillets kerneværdier, såsom vind/tab og progression/regression, hvilket driver udviklingen i sport (Tangen, 2014). Grundlæggende synes fodbold at være et felt af kommunikation for både spillere og tilskuere. Ud fra en interaktionistisk tilgang er fodbold som aktivitet og et kulturelt fænomen, som derfor kan opfattes som et symbolsk system, der hovedsageligt medieres og udtrykkes gennem kroppen.

Traditionelt forstår vi verbal kommunikation som sprog. Denne forståelse udspringer måske fra filosoffen George Herbert Mead (Brandt, 2004), som argumenterede for, at det verbale sprog er den mekanisme, hvorved sindet er socialt konstitueret (Mead, 1967). Den menneskelige evne til at sætte ord på tanker anses som udgangspunktet for sprog, men kroppen glemmes ofte som et kommunikationsmedie af tanker og som en social konstitution af sindet, hvilket udfordrer den privilegerede status det verbale sprog har.

Med inspiration fra den tyske poet Bertold Auerbach, som skrev: "Musik er det universelle sprog, det eneste, som ikke kræver oversættelse" (Auerbach, 2013, s. 62), argumenterer vi for, at ligesom musik kan fodbold også forstås som et universelt sprog. Filosoffen Ludwig Von Wittgenstein er kendt for hans analogi om sprog som et spil - en analogi han formodentlig tænkte på, da han passerede en fodboldbane (Chihara \& Fodor, 1965). Wittgenstein benytter skak som eksempel, når han skal forklare sprog som et spil. Skak spilles med et sæt regler, ligesom sprog bliver talt med et sæt af grammatiske regler; hvert træk kan opfattes som et argument i en diskussion, og det eksisterer pga. den enkelte spiller, personen som taler sproget. Lidt ligesom Wittgenstein, bruger lingvisten Saussure ligeledes skak som en analogi for sprog, og tilføjer at hver enkel brik i sig selv ikke er en del af spillet, men kun bliver en del af spillet, når det er anerkendt som værdifuldt i eller i henhold til spillet (Harris, 1988). I samme forstand, argumenterer Saussure for, at ord kun giver mening, når de benyttes på den rigtige måde $\mathrm{i}$ sprogsystemet. Vi argumenterer for, at en aflevering i sig selv ikke indeholder nogen værdi udenfor systemet, men er anerkendt som værdifuld indenfor fodboldsystemet. Saussure definerer ethvert sprog til at have to komponenter: Et sprogsystem og sprogbrugere (Danesi, 2003). Derfor kan fodbold karakteriseres som et sprog, der indeholder et system med standardiserede, specifikke spilleregler på tværs af nationale grænser, og brugere med rigtige valg og aktioner indenfor spillet. Alle fodbolddeltagere såsom spillere, trænere, tilskuere og medier kan karakteriseres som sprogbrugere indlejret $\mathrm{i}$ 
forskellige kollektive sociale institutioner, såsom nationale kulturer, hvilket påvirker deres valg i spilsituationer.

Forfatteren Eduardo Galeano kommenterer: "en spillestil er en måde at agere på, som afslører hvert fællesskabs unikke profil og bekræfter retten til at være forskellig" (Galeano, 2013, s. 209). At opfatte fodbold som et sprog betyder således, at de forskellige dialekter er udtrykt i aktioner på banen såsom temposkift, skift i tyngdepunkt og ændringer af retninger i rummet, og alle disse afslører et individs tilknytning og identifikation med et særligt fællesskab, hvilket Maguire kalder meningsankre (Maguire, 2000). Imidlertid oplever nationale fodboldkulturer effekten af en global tid/rumkomprimering, hvilket Bosman-dommen, afsagt af Europadomstolen i december 1995, måske har øget ved at tillade, at professionelle spillere hyppigt kan migrere mellem lande (Maguire \& Pearton, 2000). Selvom et studie har konkluderet, at reglen ikke havde nogen effekt på den konkurrencemæssige balance på nationalt plan på tværs af lande, kan stilen og meningen ved at spille være blevet påvirket (Frick, 2009). Reglen sammen med global tid/rumkomprimering har måske standardiseret handlingerne og meningerne på banen henimod en mere homogeniseret trend (Wagner, 1990), og som et resultat heraf vil dialekterne af fodboldsproget måske uddø. Så vidt vi ved er dette ikke blevet empirisk undersøgt, selvom sådanne studier kan udfolde væsentlig viden om de globale processer mellem forskellige nationale fodboldkulturer.

Denne artikel har til formål at beskrive, hvordan handlinger på fodboldbanen er relateret til de forskellige nationale forståelser af fodbold, og hvordan disse handlinger bliver til talte dialekter indenfor fodboldsproget. Endvidere vil vi gerne analysere kongruensen mellem landsholdenes kultur og den tilhørende nationale fodboldkultur. Vi argumenterer for, at en dybdegående analyse er nødvendig for at forstå hvordan og hvorfor fodbolddialekter adskiller sig mellem udvalgte landshold og fodboldkulturer. Dette tilvejebringer en bedre forståelse af, hvordan landshold fungerer, og hvad de repræsenterer i en globaliseret verden. I vores studie undersøger vi to landshold og fodboldkulturer gennem en empirisk undersøgelse i en systematisk, men ikke udtømmende kulturanalyse. Vi gør brug af kvalitative data i form af dokumenter og videoer som opbakning til vores kulturanalyse.

Den følgende sektion fremsætter en teoretisk ramme for undersøgelsen. Den anden del præsenterer studiets design og metodologi. Hovedfundene og resultaterne er illustreret i den tredje del, og den sidste del præsenterer konklusionerne og præsenterer anbefalinger for fremtidige studier.

\section{Teoretisk Ramme}

\section{Kultur i et organisatorisk perspektiv}

I denne artikel er vi inspireret af et funktionalistisk perspektiv på organisatorisk kulturteori, hvilket skal forstås som et kollektivt fænomen - en uafhængig, stabil og social enhed (Schein, 1990). Vi har valgt at inkludere dette teoretiske standpunkt fordi vi mener, at det forener ideen om fodbold som et sprog og den funktionalistiske kulturteori. Edgar Schein argumenterer for, at en enhver kultur består af tre niveauer: artefakter, værdier og grundlæggende antagelser. Artefakter henviser til fysisk udseende og kommunikation, men også til centrale verbale artefakter såsom begreber eller filosofiske udsagn. Dette niveau er let at observere, men svært at dechifrere. Værdier er mindre synlige og findes som sociale principper, normer, mål, og i måden, hvorpå medlemmer af en kultur beskriver deres kultur til andre. Grundlæggende antagelser er underliggende årsager til handlinger, som normalt eksisterer på et ubevidst plan, men som tages for givet og er derfor udledt af forskerne (Schein, 1990). I en fodboldkontekst kan hver spiller og hans eller hendes handlinger opfattes som et artefakt - et konkret symbol i bevægelse, som er indlejret i værdier og grundlæggende antagelser. De grundlæggende antagelser er essentielle for de åbenlyse forskelle på handlingerne på fodboldbanen, og tillader os at forstå årsagerne til særskilte handlinger på banen.

Vi har argumenteret for, at fodbold kan defineres som et sprogligt system, der opererer med handlinger som ord, således at dialekterne indenfor det sproglige system bliver til et specifikt symbolsk system, fordi symbolerne indebærer forskellige meninger til forskellige modtagere. I dette tilfælde indeholder dialekterne indenfor fodbold sandsynligvis forskellige symbolske systemer, som er baseret på forskellige antagelser. Det tyder på, at de grundlæggende antagelser er årsagen til fodbolddialekterne indenfor forskellige nationale systemer - med flere eller færre variationer på landsholdet og klubber indenfor systemet. Vi opfatter både landshold og nationale sportskulturer som stabile sociale enheder. Disse enheder eller grupper har en særskilt kultur, der kan defineres som "... hvad en gruppe tillærer over en periode, $i$ takt med at gruppen løser dens problemer med at overleve $i$ et eksternt miljø og dens problemer med intern integration" (Schein, 1990, s. 14). Intern integration skaber sammenhold mellem gruppemedlemmer i forhold til organisationens værdier. For eksempel, når unge fodboldspillere bliver integreret til en respektiv fodboldkultur, bliver de oplært til både at spille og opfatte fodbold ud fra en bestemt kulturel forståelse. Eksterne tilpasninger refererer på den anden side til kulturens påkrævede tilpasning til dens omgivelser. Eksempelvis når et landshold oplever fiasko bliver spillestilen måske ændret, hvilket leder til nye værdier eller endda grundlæggende antagelser om at spille, og således ændring af kulturen.

\section{Metodologi}

Videnskabelige metoder og redskaber

De fleste studier i organisationskultur benytter skriftligt eller verbalt indhold som analyseenhed (Martin \& Siehl, 1983). Imidlertid bør dokumenter, ifølge Bryman, anerkendes som et bredt begreb indeholdende fysiske objekter, fotografier og teknologier (Bryman, 2012). Et bredt udsnit af studier har undersøgt fysiske symboler ved at koble disse til meningsmønstre gennem 'den hermeneutiske dimension' (Gagliardi, 1990). For eksempel blev fotografier brugt som empirisk kilde i et studie af kunder, hvilke afslørede kulturelle antagelser på en nonverbal, men væsentlig måde For eksempel, et studie om kunder indeholdende fotografier som en empirisk kilde viste kulturelle formodninger i en non-verbal, men afgørende vej (Gagliardi, 1990). Larsen og Schultz fandt, at de tydelige fysiske symboler indenfor en organisation tjener som en utilsigtet måde at fremhæve organisationskulturen (Larsen \& Schultz, 1990), mens Berg og Kreiner viste, hvordan arkitekturen i firmaer tjente som symboler på strategiskprofil og status (Berg \& Kreiner, 1990).

I denne artikel benytter vi en kombination af skriftlige dokumenter og videoer fra udvalgte fodboldkampe som analyseenhed. Derfor blev data indsamlet ved anvendelse af dokumentanalyse, hvilken inkluderede både tekstanalyse og videoanalyse af hver nationale fodboldkulturer og landshold. For at forstå de tre kulturelle 
niveauer (Schein, 1990) på landsholdene, er specifikke handlinger på banen blevet inkluderet, idet disse indikerer den aktuelle kultur i aktion, artefakterne, på landsholdene. Endvidere giver de skriftlige dokumenter os indsigt $\mathrm{i}$ værdierne.

Som nævnt i vores teoretiske udgangspunkt, er grundlæggende antagelser ikke lette at udlede. Vi havde ikke muligheden for at studere forskellige fodboldkulturer gennem omfattende observationsstudier, hvilket ville være at foretrække, når der foretages en kulturanalyse. I stedet undersøgte vi både videnskabelige artikler og populære bøger tilgængelige på engelsk, som alle fokuserede på fodboldkultur og spillestil. Da vi var nødt til at udlede vores grundlæggende antagelser fra dokumentanalyse, valgte vi to af de bedst beskrevne fodboldnationer i populær og videnskabelig litteratur med henhold til spillestil og national fodboldkultur - Brasilien og I talien. Endvidere deltog begge nationer ved de sidste to verdensmesterskaber. Vi udledte de grundlæggende antagelser gennem struktureret meningskodning (Huberman og Miles, 2002) af videnskabelige artikler og populære bøger tilgængelige på engelsk. I vores kodningsproces stillede vi flere spørgsmål, som førte til vores beskrivelse af de grundlæggende antagelser, som kan findes i skemaet for dokumentanalysen. I kodningsfasen blev den overensstemmelse mellem forskerne (Armstrong et al., 1997; Huberman \& Miles, 2002) forstærket gennem en tredje forsker, der kodede stikprøver fra dokumenterne og gennem diskussioner af forskellige kodninger (Kvale, 1996). Vi benyttede videoer fra kampe fra verdensmesterskaberne i 2010 og 2014 til at indfange handlingsartefakterne på landsholdene, og dokumenterne blev benyttet til analysen af landsholdskulturen i Brasilien og I talien. Videoanalysen blev udført på alle kampene ved verdensmesterskaberne, som hver nation spillede i 2010 og 2014, fordi de repræsenterer centrale fysiske og handlingsorienterede artefakter. Rationalet bag dette var, at data indsamlet fra et højere konkurrencemæssigt niveau er mere pålidelige end data indsamlet fra et lavere niveau (Ericsson, 1996), idet alle interessenter, særligt spillere og trænere og nationer, prioriterer og værdsætter turneringen højt. At undersøge data indsamlet fra online kilder er blandt de metodiske fremgangsmåder som forskere anvender med hensyn på at undersøge spillestile (Pollard \& Gómez, 2009). Materialet fra kampene blev indsamlet fra et dansk online bibliotek (http:// www.statsbiblioteket.dk, 2014). Vi analyserede tre italienske og fem brasilianske kampe fra verdensmesterskaberne i 2010 og tre italienske kampe og syv brasilianske kampe fra verdensmesterskaberne i 2014.

$\mathrm{Vi}$ anerkender, at ingen kultur kan analyseres objektivt, fordi enhver beskrivelse af menneskelig interaktion indeholder en grad af social konstruktion (Gullestrup, 2007). Derved er vi klar over, at vi er indlejret i en dansk fodboldkultur, og at dette er vores kulturelle ståsted. I vores forsøg på at opnå overensstemmelse mellem forskerne, har vi udviklet et analyseskema med inspiration fra et dansk studie om fodboldspillere fra Trinidad og Tobago og tilpasset det formålet med denne undersøgelse (Almind \& Madsen, 2003). Skemaet inkluderer handlinger såsom højt eller lavt tempo, ændring af tempo, samt retninger i rummet såsom at spille bolden pluralistisk eller at spille bolden mere direkte mod modstanderens mål. Disse kategorier blev valgt, idet de alle på forskelligvis forsøger at indfange forskellige handlinger i spillet. Disse handlinger er tænkt som handlingsartefakter, der er centrale for at forstå kulturen indenfor handlingerne.

Alle kampene blev kodet ved at benytte analyseskemaet. Hver forsker fandt et kollektivt mønster i hver kategori for at finde de handlingsartefakter, som blev mest observeret. For det meste blev nuancer til kategorierne kun fundet, dog med få undtagelser. En er Brasilien i 2014 som ændrede deres handlingsartefakter drastisk i både semifinalen og i kampen om tredjepladsen. Siden mønsteret på handlingsartefakterne var meget forskellige fra de andre kampe, satte vi vores lid til de foregående kampe, da handlingerne på banen i disse kampe syntes mere intentionelle. Endvidere blev der identificeret små uoverensstemmelser mellem forskerne i få kategorier. Begge forskere præsenterede kategorierne og diskuterede forskellene i forhold til at opnå intersubjektiv konsensus (Gillespie \& Cornish, 2010).

Tabel 1 præsenterer handlingsartefakterne fra landsholdene ved verdensmesterskaberne i 2010 og 2014, mens tabel 2 illustrerer den kulturelle analyse af værdier og grundlæggende antagelser for hvert landshold og nationale fodboldkultur. Tabellerne bliver ikke diskuteret $\mathrm{i}$ detaljer, men de giver et overblik over vores analytiske fremgangsmåde og resultaterne fra video- og dokumentanalysen.

Analyse

Fodboldorganisationskultur: I taliensk fodboldkultur og landsholdet Artefakter

Det, der særligt skiller sig ud i videoanalysen af det italienske landshold, er ændringerne i næsten alle kategorier vedrørende handlingsartefakterne fra verdensmesterskaberne i 2010 til verdensmesterskaberne i 2014. Vi fandt, at den eksterne kommunikation var i nogen grad hård i 2010, hvilket er forbedret i 2014 til en skiftende tendens. Andre tilpassede centrale handlingsartefakter er boldens bevægelser, spillernes bevægelser og tempoet. Det er interessant, at den eneste kategori, hvor de samme karakteristika fra de to verdensmesterskaber er ens, er spillernes kollektive rytme. Værdier

Vi udleder, at nøgleværdien udtrykt af forskellige insidere og outsidere i miljøet inkluderer begrebet Catenaccio. Denne term refererer til en defensiv spillestil, men også en særlig indstilling blandt deltagerne i spillet. Dette leder os til den mest benyttede italienske kliché: 'Vores førsteprioritet er at holde målet rent' (Foot, 2007, s. 134), som igen leder til den defensive taktiske disposition i spillet. Den defensive indstilling kan udtrykkes gennem den observerede kollektive rytme, idet dette kendetegn kan være resultatet af den indstilling.

Grundlæggende antagelser

Vi udleder, at den nationale fodboldkultur i Italien er karakteriseret ved et kulturelt paradigme, som indeholder seks forbundne grundlæggende antagelser. Den første antagelse er: Fodbold spilles med rationalisme. Denne antagelse gennemsyrer hele kulturen, idet både diskursen og handlingerne på og udenfor banen henleder til denne indstilling. Titlen på selvbiografien af den italienske spiller Pirlo understreger dette: "Jeg tænker, derfor spiller jeg" (Pirlo \& Alciato, 2014). Den anden antagelse afslører, hvad der karakteriserer et vinderhold; et vinderhold er et godt defensivt hold. Denne er stærkt sammenhængende med nøgleværdien, men den fremgår også i form af antal scorede mål sammenlignet med Brasilien. Et studie af Filho og kolleger fandt, at igennem 80 år havde det brasilianske hold i gennemsnit scoret 2,0 mål per kamp, hvorimod det italienske hold havde scoret 1,6 mål per kamp. Lignende tendenser blev fundet på det nationale liganiveau $\mathrm{i}$ begge lande (Filho et al., 2013). Vi udleder den tredje antagelse fra dokumentanalysen og finder den at være: Et vinderhold vinder ved hjælp af alle midler. For eksempel, "Et italiensk 


\section{Sport and Exercise Psychology}

publikum ville tiljuble den handling som redder et mål, på trods af et gult kort, endda et rødt kort..." (Goldblatt, 2008, s. 432). I midlertid indikerer den eksterne kommunikation, som vi fandt i videoanalysen, ikke denne hårdførhed. Derimod tyder handlingsanalysen på en udvikling på det italienske landshold fra en $\mathrm{i}$ nogen grad hård ekstern kommunikation i 2010 til en mere skiftende tendens i 2014. Derfor er den grundlæggende antagelse, som vi fandt $\mathrm{i}$ dokumentanalysen, ikke fundet at være specielt sammenhængende med det observerede handlingsartefakt. Den fjerde antagelse, fodbold handler om at vinde, er tæt relateret til den femte antagelse, som fortæller, hvad der er vigtigst i fodbold: Kampens resultat. Dette manifesterer kernen i kulturen, som de tre niveauer er centreret omkring. Viljen til at vinde bliver dynamisk, idet der ikke er nogen specifik måde at opnå dette. Den sjette antagelse, kollektivisme, er imidlertid et dogme som middel til at vinde. Dette dogme ser ud til at være ganske stabilt $\mathrm{i}$ både vores videoanalyse og dokumentanalyse, hvilket understreger den kulturelle værdi af kollektivisme, som synes at eksistere indenfor italiensk fodboldkultur og også på det italienske landshold. Den bibeholdte kollektive rytme indikerer en stærk kulturel norm indenfor den nationale fodboldkultur, hvorimod de andre kategorier til en vis grad har ændret sig i de fire år mellem verdensmesterskaberne. $\mathrm{Vi}$ udleder, at handlingsartefakterne fra verdensmesterskaberne i 2010 til en vis grad er konsistente med de grundlæggende antagelser. Handlingsartefakterne fra verdensmesterskaberne i $2014 \quad$ skifter bemærkelsesværdigt, hvilket indikerer klare ændringer i spillestilen på landsholdsniveau, men ikke direkte som en ændring i konsistens med de fleste grundlæggende antagelser.

Opsummerende er organisationskulturen $\mathrm{i}$ italiensk fodbold og på landsholdet karakteriseret ved nogen grad af sammenhæng mellem forskellige kulturelle niveauer ved verdensmesterskaberne i 2010 og 2014. Der er dog uoverensstemmelser såsom hårdheden ved den eksterne kommunikation, hvilket kunne være et resultat af en kulturel ændring eller som en taktisk tilpasning fra landsholdet. Landsholdets handlingsartefakter har til en vis grad ændret sig imellem de to verdensmesterskaber. Den betydelige ændring i handlinger på banen er måske som følge af en kulturel ændring, hvilket udskiftningen af landsholdstræneren kunne indikere. Dette kan dog også skyldesen bevidst ændring i holdets taktik, hvilket passer med de fleste af de udledte grundlæggende antagelser.

Tabel 1. Analyse af Brasiliens og I taliens handlende artefakter ved verdensmesterskaberne i 2010 og 2014

\begin{tabular}{|c|c|c|c|c|c|}
\hline \multirow{2}{*}{\multicolumn{2}{|c|}{$\begin{array}{l}\text { Temaer } \\
\text { Rum }\end{array}$}} & Brasilien 2010 & Brasilien 2014 & Italien 2010 & Italien 2014 \\
\hline & & \multirow{2}{*}{$\begin{array}{l}\text { For det meste } \\
\text { små områder }\end{array}$} & \multirow[b]{2}{*}{$\begin{array}{l}\text { For det meste } \\
\text { små områder }\end{array}$} & \multirow[b]{2}{*}{$\begin{array}{l}\text { Relativt store } \\
\text { områder }\end{array}$} & \multirow{3}{*}{$\begin{array}{l}\text { Små til } \\
\text { mellemstore } \\
\text { områder } \\
\text { Skiftende } \\
\text { mellem langs } \\
\text { jorden og i } \\
\text { luften }\end{array}$} \\
\hline $\begin{array}{l}\text { Primære } \\
\text { spilområder }\end{array}$ & Små/store & & & & \\
\hline $\begin{array}{l}\text { Bevægelse med } \\
\text { bolden }\end{array}$ & $\begin{array}{l}\text { På jorden/ i } \\
\text { luften }\end{array}$ & $\begin{array}{l}\text { For det meste } \\
\text { langs jorden }\end{array}$ & Langs jorden & $\begin{array}{l}\text { Langs jorden, } \\
\text { men for det } \\
\text { meste i luften på } \\
\text { den angribende } \\
\text { tredjedel }^{\text {a }}\end{array}$ & \\
\hline \multicolumn{6}{|l|}{ Tid } \\
\hline Tempo & $\begin{array}{l}\text { Langsom/ } \\
\text { skiftende/ } \\
\text { hurtig }\end{array}$ & Skiftende & $\begin{array}{l}\text { For det meste } \\
\text { hurtigt }\end{array}$ & $\begin{array}{l}\text { Relativt } \\
\text { langsomt }\end{array}$ & Skiftende \\
\hline Rytme & $\begin{array}{l}\text { Individuel/ } \\
\text { kollektiv }\end{array}$ & $\begin{array}{l}\text { For det meste } \\
\text { kollektiv }\end{array}$ & $\begin{array}{l}\text { For det meste } \\
\text { individuelt }\end{array}$ & Kollektivt & Kollektivt \\
\hline \multicolumn{6}{|l|}{$\begin{array}{l}\text { Intern } \\
\text { kommunikation }\end{array}$} \\
\hline $\begin{array}{l}\text { Spillernes } \\
\text { bevægelse }\end{array}$ & $\begin{array}{l}\text { Sidelæns/ } \\
\text { mod mål }\end{array}$ & $\begin{array}{l}\text { Både sidelæns og } \\
\text { mod mål }\end{array}$ & $\begin{array}{l}\text { For det meste } \\
\text { mod mål }\end{array}$ & $\begin{array}{l}\text { For det meste } \\
\text { mod mål }\end{array}$ & $\begin{array}{l}\text { For det meste } \\
\text { mod mål }\end{array}$ \\
\hline \multicolumn{6}{|l|}{$\begin{array}{l}\text { Ekstern } \\
\text { kommunikation }\end{array}$} \\
\hline $\begin{array}{l}\text { Interaktion med } \\
\text { modstandere }\end{array}$ & Hård/blød & Middel & Hård & $\begin{array}{l}\text { I nogen grad } \\
\text { hård }\end{array}$ & $\begin{array}{l}\text { Skiftende } \\
\text { mellem hård og } \\
\text { blød }\end{array}$ \\
\hline
\end{tabular}

a "Den angribende tredjedel" betyder den sidste tredjedel af banen, der er tættest på modstanderens mål.

Fodboldorganisationskultur: Brasiliansk

fodboldkultur og landsholdet

Artefakter

Et essentielt verbalt artefakt er Joga Bonito (dvs. det flotte spil) som udtrykker en talemåde, der også afspejler værdierne (Filho et al., 2013). Dog finder vi ikke dette $i$ overensstemmelse med spillestilene observeret i begge verdensmesterskaber. I 2010 spillede holdet mest kollektivt, hvorimod holdet i 2014 spillede med en hårdere spillestil. Til en vis grad er disse handlinger usammenhængende med værdierne og derfor i uoverensstemmelse med den nationale fodboldkultur. Endvidere udleder vi, at de centrale handlingsartefakter er både konsistente og skiftende mellem verdensmesterskaberne i 2010 og 2014. Det brasilianske landshold spiller konsekvent i små områder og ved begge verdensmesterskaber spilles bolden langs jorden, hvilket til en vis grad er sammenhængende med det verbale artefakt Joga Bonito. Vores analyse viser dog også et skift fra en kollektiv rytme i 2010 til en individualistisk rytme i 2014. Dette er en interessant ændring sammenlignet med ændringerne fundet $\mathrm{i}$ ekstern kommunikation. Vi udleder, at den eksterne kommunikation tilpasser sig fra middel til hård, hvilket indikerer en ændring mod en hårdere spillestil. Sammen med ændringen i tempo fra skiftende til hurtigt og spillernes bevægelse mod mål, indikerer handlingsartefakterne i nogen grad en kulturel ændring i spillestilen, hvilket ikke er i fuldstæendig i overensstemmelse med de verbale artefakter, værdierne og de grundlæggende antagelser, som vi vil vise i de næste afsnit. 
Tabel 2. Tabellen illustrerer de to niveauer af de to nationers nationale fodboldkultur: Italien og Brasilien.

\begin{tabular}{lll}
\hline Værdier & Italien & Brasilien \\
\hline & målet rent" & $\begin{array}{l}\text { "Det bedste forsvar er et godt } \\
\text { angreb" }\end{array}$ \\
\hline
\end{tabular}

Basale antagelser

Hvordan skal fodbold spilles?

Hvad karakteriserer et vinderhold?

Fodbold spilles med rationalisme
Et vinderhold er et godt defensiv hold

Et vinderhold vinder ved hjælp af alle nødvendige midler

\section{Hvad handler fodbold om?}

Fodbold handler om at vinde

Hvad er det mest vigtige i kampen? Et hold karakteriseres ved

Kampens resultat Kollektivisme

\section{Fodbold spilles med æstetik} Et vinderhold er et godt offensivt hold

Fodbold handler om at vise

færdigheder

Skønheden ved spillet Individuelle kvaliteter

\section{Værdier}

Nøglekerneværdien i Brasilien siges at være: "Det bedste forsvar er et godt angreb" (Filho et al., 2013, s. 214). Denne indstilling skaber en klar fokus på det offensive aspekt af spillet. Værdien er vanskelig at tyde direkte fra vores analyse af handlingsartefakter, men kan være en særlig indstilling til holdets taktik og handlingerne på banen.

Grundlæggende antagelser

Fra vores dokumentanalyse udleder vi, at den nationale fodboldkultur i Brasilien synes at indeholde fem sammenhængende karakteristiske grundlæggende antagelser fra dette kulturelle paradigme. Den første antagelse, Fodbold spilles med æstetik, er i overensstemmelse med handlingsartefakterne såsom den individuelle rytme fra verdensmesterskaberne i 2014 og værdierne. Den anden antagelse, Et vinderhold er et godt offensivt hold, er sammenhængende med det verbale artefakt Joga Bonito, da fokus er på ekspertisen med bolden. Den tredje antagelse, Fodbold handler om at fremvise færdigheder, findes i den brasilianske forfatters Freyres beskrivelse af brasiliansk fodbold: "... vores afleveringer... vores tricks... det er noget, der hænger sammen med dans, med capoeira, den brasilianske fodboldstils varemærke" (Brown, 2014, s. 115). Den fjerde antagelse, spillets skønhed, indikerer hvad der opfattes som det vigtigste aspekt ved spillet, hvilket gentager sig i artefakterne og kerneværdierne. Den individuelle offensive præstation i spillet er nødvendig for at skabe det æstetiske krav, hvilket fører os til den femte antagelse, at et hold er karakteriseret ved individuelle kvaliteter. I midlertid ses det i analysen af de handlingsorienterede artefakter, at rytmen i spillet er kendetegnet ved både individualisme og kollektivisme, hvilket indikerer en uoverensstemmelse mellem handlingsartefakterne og de grundlæggende antagelser. Endvidere er omstillingen til en hårdere spillestil i 2014 i dokumentanalysen ikke vurderet som repræsentativ, og derfor ikke sammenhængende med den nationale fodboldkultur.

Selv om organiseringen af den brasilianske fodboldkultur og landsholdet overordnet set synes at være karakteriseret ved sammenhæng mellem forskellige niveauer, er visse karakteristika til dels i uoverensstemmelse med den nationale kultur. Bevægelsen fra en kollektiv til en individualiseret rytme er en bevægelse mod de udledte grundlæggende antagelser, men det indikerer også et dynamisk forhold med handlingerne på banen. En anden uoverensstemmelse er hvordan den hårdere spillestil til verdensmesterskaberne i 2014 i nogen grad forstyrrer de grundlæggende antagelser relateret til æstetik. Dette kan anses som en mindre kulturel justering, men det kan også opfattes som en kulturel tilpasset spillestil, som til nogen grad er i kontrast til de grundlæggende antagelser, udledt fra den nationale fodboldkultur i Brasilien. I midlertid kan det også tilskrives et dynamisk skifte i de grundlæggende antagelser i den nationale fodboldkultur, om hvad brasiliansk fodbold er, hvordan det spilles, og hvordan brasilianere opfatter fodbold.

\section{Diskussion}

Kulturanalysen af de to landshold og fodboldkulturer afslørede fund som opsummeres i det følgende.

\section{Landshold som spilledialekter}

Vi har fundet ud af, at handlingsartefakterne klart viser ændringer på begge landshold, men for det meste moderate ændringer. Endvidere illustrerer den empiriske analyse også, at fodbolddialekter er baseret på forskellige antagelser og forståelser for spillet, resulterende i forskellige handlinger på banen mellem de udvalgte nationer. Dette indikerer, at landsholdene til en vis grad tilpasser deres spillestil mellem de to verdensmesterskaber og derfor til en vis grad også udvikler sig kulturelt over tid. På trods af variationerne i handlingsartefakter, viser kulturanalysen en vis sammenhæng mellem grundlæggende antagelser, den nationale fodboldkulturs skueværdier og handlingerne fundet i landsholdenes spillestile. Den empiriske analyse viser også forskelle mellem de nationale fodboldkulturer og landsholdene i handlingerne og forståelsen af fodbold, hvilket understøtter opfattelsen af, at spillestile kan forstås som dialekter indenfor sproget i fodbold. International sport siges at være en national kamp, hvor landshold symboliserer nationer: Det forestillede fællesskab af millioner synes mere virkeligt/ægte som et hold bestående af 11 navngivne spillere. Individet, selv den der hepper, bliver selv et symbol på sin nation" (Hobsbawm, 1990, s. 143). Nationalsymbolet handler ikke bare om at vinde eller tabe kampen, men også om at udvise en specifik national identitet i en international turnering. På trods af den globale tid/rum-komprimering indikerer vores resultater, at national identitet stadig til en vis grad udtrykkes gennem de symbolske handlingsartefakter, som spillere konstruerer gennem deres bevægelser på banen. Denne proces bliver måske vedligeholdt, fordi andre sprogbrugere såsom trænere, tilskuere, kommentatorer etc. også genskaber symbolske handlinger på banen og dermed stabiliserer grundlæggende antagelser.

\section{Dynamiske og stabile nationale holdkulturer?}

De fundne dialekter indenfor fodboldsproget synes dog ikke at være stabile kulturelle skitser, men derimod mere 
dynamisk kulturelle handlinger, der for det meste synes at operere indenfor en række af værdier og grundlæggende antagelser fra den nationale fodboldkultur, som i nogle tilfælde også kan være i uoverensstemmelse med disse. For eksempel fandt vi ikke en særlig individualistisk rytme i brasiliansk fodbold $\mathrm{i}$ analysen af handlinger på banen i 2010, hvilket kunne indikere en ændring i handlingerne lige så vel som i de grundlæggende antagelser på landsholdet. Vi kan kun gætte på, hvorfor denne ændring er fundet $\mathrm{i}$ analysen. Et forslag kan være, at det brasilianske landshold i 2010 bevidst havde tilpasset sig en mere europæisk spillestil. Den berømte brasilianske sociolog og forfatter Gilberto Freyre proklamerede allerede dette som en nødvendig udvikling: "Vi bliver nødt til at forsone (den brasilianske) individualisme med (den europæiske) disciplin" (Maranhao, 2007, s. 518). Hvis den europæiske dialekt forstås som en kollektiv rytme er citatet måske ret præcist, idet I talien som en europæisk repræsentant i vores analyse interessant nok spiller med en kollektiv rytme til begge verdensmesterskaber. Den brasilianske ændring kan være opstået på grund af kravene fra befolkningen, som lægger vægt på præstation som væsentligt, og derved have skabt den umiddelbare ændring i spillestil og forståelse af spillet. Det kulturelle skifte kan være blevet acceptabelt for sprogets brugere, selvom det forandrer det brasilianske spilfundament- og derved skaber en form for dikotomi mellem landsholdskulturen og den nationale fodboldkultur. Derimod blev det europæiske kollektivistiske spor, ifølge vores analyse, ændret på det brasilianske hold i 2014, da de syntes at vende tilbage til mere individuelle handlinger, hvilket bedre afspejler Brasiliens spillestil ifølge den nationale fodboldkultur. I kke desto mindre synes begge landshold at have ændret deres dialekt, og derfor til en vis grad skabt en kulturel tilpasning. Årsagerne til disse kulturelle tilpasninger er flere, og vores analyse giver ikke mulighed for at give os et præcist svar. Men en mulig forklaring på variationerne på banen kan være udskiftningen af trænere på begge landshold. Mellem verdensmesterskaberne i 2010 og 2014, udskiftede Italien deres landstræner Marcello Lippi og erstattede ham med Cesare Prandelli, mens Brasilien skiftede fra Carlos Alberto Parreira til Luiz Felipe Scolari. Idet vi har fundet, at sprogbrugerne sammenskaber de symbolske handlinger, synes en kulturel transformation vanskelig. Schein argumenterer dog for, at ledere og kulturer er særligt sammenflettede i både organisationen og kulturen, hvilket gør trænere og managere til de mest sandsynlige frontløbere i den kulturelle udvikling af spillet (Schein 2010). Derfor kan udskiftningen af en landstræner tilsyneladende skabe en mulighed for at forandre handlinger på banen. Alligevel skaber den nationale fodboldkultur underlæggende kulturelle mål, som skal opnås i spillet ud over at vinde kampen. Disse kulturelle mål kunne være karakteristika såsom æstetik, hårdt arbejde og kollektiv rytme indenfor spillestilen, hvilket til en vis grad skaber en kulturel ramme, som den nye landstræner måske opererer indenfor.

\section{Migration og homogenisering}

Næsten alle brasilianske spillere fra landsholdet bor i dag i europæiske lande og er som konsekvens heraf eksponeret for europæiske forestillinger om fodbold. Dermed er skiftet til en mere individualistisk rytme fra verdensmesterskaberne i 2010 til 2014 endnu mere interessant, fordi det er modstridende med den åbenlyse homogenisering mod en mere europæisk spillestil på det brasilianske landshold. Vi observerede at det brasilianske landshold ved verdensmesterskaberne i 2010 havde en mere kollektiv rytme modsat den beskrevne nationale fodboldkultur. På den ene eller anden måde ændrede rytmen sig til en overvejende individuel rytme, hvilket tyder på en ændring i kulturen mellem de to verdensmesterskaber. Den observerede ændring i rytmen mellem de to verdensmesterskaber kan være karakteriseret som en form for 'kulturel looping'; landsholdet bevægede sig væk fra den egentlige fodboldkultur, kun for at vende tilbage til denne spillestil eller dialekt under verdensmesterskaberne i 2014. Spørgsmålet er hvorfor den sandsynlige kulturelle looping forekommer mellem to verdensmesterskaber. Eksponeringen for europæisk fodbold kunne uhensigtsmæssigt have ændret spillestilen i 2010, men manglen på tilfredsstillende resultater har måske presset det nationale fodboldforbund i Brasilien til at ansætte en landstræener, Scolari, med en mere brasiliansk spillestil. Det er også sandsynligt, at rollen som vært ved verdensmesterskaberne i 2014 pressede forbundet til at vælge en landstræner med en mere traditionel brasiliansk spillestil, fordi dette ville vise en mere 'rigtig' brasiliansk fodboldkultur og medføre mere støtte til sprogbrugerne.

Både det brasilianske og italienske landshold synes for det meste sammenhængende med de nationale karakteristikker. Selvom begge lande har haft en overdreven tilgang af udenlandske spillere til de nationale ligaer (Maguire \& Pearton, 2000), synes begge lande at have været i stand til at bibeholde en dialekt, og har således forhindret en homogeniseret international spillestil. I vores kulturanalyse finder vi, at de nationale fodboldkulturer inspirer de observerede landsholdskulturer på trods af, at der er variationer i handlingsartefakter. Årsagen til hvorfor dette er tilfældet kan være det store pres for at skabe resultater på nationalt niveau, spillere der kan rekrutteres og også trænerens kulturelle baggrund. Disse faktorer kan erstatte en idealiseret national fodboldkultur med en mere kortsigtet landsholdskultur, som inkluderer en kulturel adaptation med hensyn til at kunne konkurrere internationalt.

\section{Konklusion}

På trods af globaliseringen og migrationstendenser indikerer vores kulturanalyse, at den nationale fodboldkultur og landsholdet forbliver relativt stabile, hvilket til en vis grad tillader os at anskue de forskellige spillestile som dialekter indenfor fodboldsproget. Dette antyder, at fodbold som sprog stadig har dialekter, der manifesterer sig symbolsk gennem de forskellige bevægelser på banen. Imidlertid blev nogle kulturelle uoverensstemmelser fundet mellem den brasilianske fodboldkultur og den nationale kultur, hvilket kan skyldes globaliseringen eller migrationstendenser. Dermed er landshold, i en global verden, måske ikke repræsentative for den nationale fodboldkultur, men er i stedet en mere eller mindre sammenhængende symbolsk artefakt indenfor den nationale fodboldkultur. Dette leder os til at tro, at der i stedet bør fokuseres på fodboldklubbers kulturer for en dialektrepræsentation af national fodboldkultur i stedet for at fokusere på landshold. Men når vores metode anvendes, opstår udfordringerne, hvis der forelægger mindre dokumentation for klubkulturerne.

At have de kulturelle perspektiver i tankerne, ville tillade fodboldtrænere og managere at handle $i$ overensstemmelse med den underlæggende kulturelle antagelse. Dette kan begrænse alternative tilgange til spillestilen. Den kulturelle indsigt kan også lette transitioner fra en national liga til en anden, hvilket vil tillade spillere at adaptere til den kulturelle forståelse af fodbold $i$ et givent land med mindre besvær, end hvad der tidligere har været tilfældet. 
Scandinavian Journal of

Sport and Exercise Psychology 
Vi vil gerne takke Mads Lange Møller-Larsen for hans bidrag til vores dataanalyse og Diana Stentoft, som reviderede et tidligt udkast til nærværende artikel.
Ingen potentielle interessekonflikter blev rapporteret af forfatterne.
Almind, K., \& K. L. Madsen. (2003). Boldspil - i clinch med kroppen og kulturen. [Ballgames - going into clinch with the body and culture]. In K. Lüders, \& N. Vogensen (Eds.), Idrætpædagogisk Årbog (pp. 119147). Aarhus: Klim.

Archetti, E. P. (1992). Argentinian football: A ritual of violence? The International J ournal of the History of Sport, 2, 209-235.

Armstrong, D, Gosling, A., Weinman, J., \& Marteau T. (1997). The place of inter-rater reliability in qualitative research: An empirical study. Sociology, 31, 597-606. doi: 10.1177/0038038597031003015.

Auerbach, B. (2013). On the heights a novel. London: Forgotten Books.

Berg, P. O., \& Kreiner, K. (1990). Corporate architecture: Turning physical settings into symbolic resources. In P. Gagliardi (Ed.), Symbols and artifacts: Views of the corporate landscape, (pp. 41-67). New York: Aldine De Gruyter.

Brandt, K. (2004). A language of their own: An interactionist approach to human-horse communication. Society \& Animals, 12(4), 299-316. doi: $10.1163 / 1568530043068010$.

Brown, M. (2014). From frontiers to football: An alternative history of latin america since 1800. London: Reaktion Books.

Bryman, A. (2012). Social Research Methods (4th ed.). Oxford: Oxford University Press.

Chihara, C. S., \& Fodor, J. A. (1965). Operationalism and ordinary language: A critique of Wittgenstein. American Philosophical Quarterly 2, 281-295. http://www.jstor.org/stable/20009178.

Danesi, M. (2003). Second language teaching: A view from the right side of the brain. Dordrecht: Kluwer Academic

Ericsson, A. K. (Ed.). (1996). The road to excellence: The acquisition of expert performance in the arts and sciences, sports, and games. New Jersey: Lawrence Erlbaum Associates.

Filho, E., Basevitch, I., Yang, Y., \& Tenenbaum, G. (2013). Is the best defense a good offense? Comparing the brazilian and italian soccer styles. Kinesiology, 45(2), 213-221.

Foot, J. (2007). Winning at all costs: A scandalous history of italian soccer. New York: Nation Books.

Frick, B. (2009). Globalization and factor mobility: The impact of the 'bosman-ruling' on player migration in professional soccer. Journal of Sports Economics, 10(1), 88-106. doi: 10.1177/1527002508327399.

Gagliardi, P. (Ed.). (1990). Symbols and artifacts: Views of the corporate landscape. New York: Aldine De Gruyter.

Galeano, E. (2013). Soccer in sun and shadow. London: Nation Books.

Gillespie, A., \& Cornish, F. (2010). Intersubjectivity: Towards a dialogical analysis. Journal for the Theory of Social Behaviour, 40, 19-46. doi: 10.1111/j.14685914.2009.00419.x.
Goldblatt, D. (2008). The ball is round: A global history of soccer. London: Penguin.

Gullestrup, H. (2007). Kulturanalyse: En vej til tværkulturel forståelse [Cultural analysis: a way to cross-cultural understanding] (4th ed.). København: Akademisk forlag.

Harris, R. (1988). Language, Saussure and Wittgenstein how to play games with words. London: Routledge.

Hobsbawm, E. J. (1990). Nations and nationalism since 1780. New York: Cambridge University Press.

Holt, R. (1989). Sport and the British: A modern history. Oxford: Oxford University Press.

Huberman, M., \& Matthew B. M. (2002). The qualitative researcher's companion. London: Sage.

Kvale, S. (1996). Interviews: An introduction to qualitative research interviewing. London: Sage.

Larsen, J., \& Schultz, M. (1990). Artifacts in a bureaucratic monastery. In P. Gagliardi (Ed.) Symbols and artifacts: Views of the corporate landscape (pp. 281-302). New York: De Gruyter.

Lever, J. (1995). Soccer madness: Brazil's passion for the world's most popular sport. Illinois: Waveland Press.

Maguire, J. (2000). Globalization and sport. In J. Coakley, \& E. Dunnning (Eds.), Handbook of Sport Studies (pp. 356-369). London: Sage.

Maguire, J., \& Pearton, R. (2000). The impact of elite labour migration on the identification, selection and development of european soccer players. Journal of Sports Sciences 18(9), 759-769. doi: $10.1080 / 02640410050120131$.

Maranhão, T. (2007). Apollonians and Dionysians : The role of football in Gilberto Freyre's vision of Brazilian people. Soccer \& Society, 8(4), 510-523. doi: 10.1080/14660970701440790

Martin, J. \& Siehl, C. (1983). Organizational culture and counterculture: An uneasy symbiosis. Organizational Dynamics, 12(2), 52-64. doi: 10.1016/00902616(83) $90033-5$

Mead, G. H. (1967). Wundt and the concept og the gesture. In C. W. Morris (Ed.), Mind, self, and society - from the standpoint of a social behaviorist (pp. 42-51). Chicago: The University of Chicago Press.

Pirlo, A. \& Alessandro A. (2014). Andrea Pirlo: I think therefore I play. Milano: BackPage Press.

Pollard, R. \& Gómez, M. A. (2009). Home advantage in football in south-west europe: Long-term trends, regional variation, and team differences. European J ournal of Sport Science 9(6), 341-352. doi: $10.1080 / 17461390903009133$.

Schein, E. H. (1990). Organizational culture. American Psychologist, 45, 109-119. doi:10.1037//0003066X.45.2.109.

Schein, E. H. (2010). Organizational culture and leadership (4th ed.). New York: John Wiley and Sons.

Tangen, J. O. (2004). Hvordan er det mulig? Skitse til en idrettssosiologi [ How is it possible? Drafts toward a sports sociology ]. Kristiansand: Høyskoleforlaget. 
Scandinavian Journal of

\section{Sport and Exercise Psychology}

Tomlinson, A., Markovits, A. S., \& Young, C. (2003).

Introduction: Mapping sports space. American

Behavioral Scientist, 46(11), 1463-1475.

doi: $10.1177 / 0002764203046011001$.

Wagner, E. A. (1990). Sport in Asia and Africa:

Americanization or mundialization? Sociology of Sport Journal, 7(4), 399-402.

Wagner, U., \& Storm, R. K. (2013). Sport as a

communication system. In M. P. Pedersen (Ed.), The

Routledge handbook of sport communication (pp.

46-55). London: Routledge. 